issued

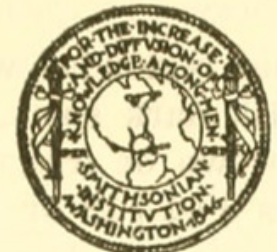

by the

SMITHSONIAN INSTITUTION

U. S. NATIONAL MUSEUM

Vol. 100

Washington : 1950

No. 3270

\title{
THREE NEW SPECIES OF FISHES OF THE GENUS CIRRHITUS (FAMILY CIRRHITIDAE) FROM THE INDO- PACIFIC
}

\section{By Leonard P. Schultz}

Recentux, in studying the fishes of the family Cirrhitidae from the northern Marshall Islands, I found three undescribed species in the genus Cirrhitus. They are described below.

\section{Genus CIRRHITUS Lacepède}

Cirrhitus LACEPÈDE, Histoire naturelle des poissons, vol. 5, p. 2, 1803. (Genotype, Oirrhitus maculatus Lacepède.)

\section{KEY TO THE SPECIES OF CIRRHITUS}

1a. Vertical scale rows from upper edge of gill opening to base of caudal fin, counted just above lateral line, 46 to 49 ; dorsal rays $\mathrm{X}, 11$ or 12 ; anal III, 6 or 7 ; gill rakers 5 or $6+1+9$ to 11 ; scales on gill membranes over isthmus very small and embedded; young with 5 or 6 vertical dark brown bars that change with growth, breaking up into round or oblong spots, which have pale centers and are bordered by a dark brown line, then a white line; background color pale (American, tropical Pacific) --rivulatus ${ }^{1}$ (Valenciennes)

$1 b$. Scale rows 44 or fewer.

2a. Head and body with numerous tiny white specks or spots, arranged in rows on sides; background coloration brownish with about 5 indistinct dark bars; no black spots; gill membranes over isthmus naked; vertical scale rows 38 and 39 ; orbital ridge low ; gill rakers $7+1+11$ (Niuafoou Island, Tonga Group) _..._._. albopunctatus, new species

$2 b$. Color pattern not of tiny white spots or specks; gill membranes over isthmus with tiny scales, somewhat embedded.

$3 a$. Head and body dorsally and anteriorly with numerous but scattered tiny dark brown or black specks; scales 41 or 42 ; orbital ridge sharp edged, high, and extending behind eye a short distance; gill rakers $6+1+10$ or 11 (Mauritius) -..._............ nigropunctatus, new species

${ }^{1}$ Cirrhitus betaurus Gill is a synonym. See Tee-Van, Zoologica, vol. 25, pt. 1, pp. 54-58, 1940. 
3b. No tiny black specks; orbital ridge not notably extending a short distance behind eye.

4a. Color pattern of snout and region below eye with numerous dark brown spots; fins barred with dark spots, but body without dark spots; body marbled with brown or irregular vertical dark brown bars; scales 42 ; gill rakers $6+1+12$ or 13 (Red Sea).

spilotoceps, new species

4b. Color pattern around head consisting of large dark blotches or dark streaks, or plain dark brownish; not as in spilotoceps.

5a. Body overlaid with dark-brown or blackish spots, in addition to a dark-brownish background more or less forming irregular bars or a marbled pattern; interspaces white; orbital ridges low, scales 39 or 40 ; gill rakers 6 to $8+1+12$ (Occana).

pinnulatus $^{2}$ (Bloch and Schneider)

5b. No dark brown or blackish spots on body in addition to background brownish coloration, more or less in form of irregular bars or a marbled pattern; often roundish white spots present with dark edges, largely or wholly occurring on the dark-brown markings; interspaces whitish (pl. 13, D) ; scales 39 or 40 ; gill rakers about $7+\mathbf{1}+\mathbf{1 1}$ (Johnston and Hawaiian Islands) -..- alternatus $^{3}$ Gill

\section{CIRRHITUS ALBOPUNCTATUS, new species}

Plate 13, A

Holotype.-U.S.N.M. No. 91883, Niuafoou Island, September 1, 1930, Lt. H. C. Kellers.

Paratype.-U.S.N.M. No. 91881, Niuafoou Island, September 13, 1930, Lt. H. C. Kellers.

Description.-The following counts are recorded for the holotype and the paratype, respectively: Dorsal rays $\mathrm{X}, 12 ; \mathrm{X}, 11$; anal III, 6 ; III, 6 ; pectoral i, 6 , vii-i, 6 , vii ; i, 6 , vii-i, 6 , vii; pelvics I, 5 ; I, 5 ; branched caudal fin rays $7+6 ; 7+6$; vertical scale rows $38 ; 39$; scales from dorsal origin to lateral line $5 ; 5$; from anal origin to lateral line $9 ; 9$; gill rakers on first gill arch $7+1+11 ; 7+1+11$; scale rows in front of dorsal origin $7 ; 7$.

Certain measurements were made on the types, and these data, expressed in thousandths of the standard length, are recorded in table 1.

Greatest depth 3.0 ; head 2.7 to 2.8 ; length of longest branched pectoral ray 4.7 to 4.8 ; longest lower simple pectoral ray 3.7 to 4.1 ; all in the standard length. Snout 3.4; eye 4.7 to 5.1; tip of snout to rear of maxillary 2.2 ; greatest depth 1.1 to 1.2 ; least depth of caudal peduncle 2.6 to 2.7 ; postorbital length of head 1.8 to 1.9 ; interorbital

${ }^{2}$ Labrus pinmulatus Bloch and Schnelder, Systema ichthyologiae, p. 264, 1801 (type locality, Tahit1).

Labrus marmoratus Lacepede, Histoire naturelle des poissons, vol. 3, pp. 438, 493, pl. 5, fig. 3, 1802 (type locality, Great Equatorial Ocean).

Cirrhitus maculatus Lacepède, ibid., vol. 5, pp. 2, 3, 1803 (no locality).

${ }^{3}$ Oirrhitus alternatus Gill, Proc. Acad. Nat. Sc1. Phlladelphia, 1862, p. 122 (type locality, Honolulu; holotype, U.S.N.M. No. 8043). 
space (bony) 6.6 to 6.8 ; least suborbital width 6.3 to 7.1 ; all in the length of the head. Least depth of caudal peduncle in its length (base of last anal ray to midbase of caudal fin) 2.5 to 2.7. Bony interorbital space 1.4 in eye.

Greatest depth opposite pelvic insertions; head blunt, profile of snout steep; interorbital space concave, orbital ridge low, gill membranes broadly joined across isthmus, free, without scales; maxillary concealed anteriorly by preorbital; lips thick, the lower one very broad, about one-half eye; lower jaw slightly shorter than upper, mouth a little oblique; cheeks with fine embedded scales, those behind eye larger; nostrils separated by a dermal isthmus, rear margin of anterior nostril with a tuft of dermal cirri; posterior tips of dorsal spines, each with a tuft of dermal cirri; no accessory pelvic scale; scales cycloid, absent on snout and dorsal surface of head; vomer with the usual triangular-shaped patch of villiform teeth; palatines with a few tiny teeth anteriorly; jaws with a band of villiform teeth, broadest anteriorly along outer margin of which are some enlarged conical teeth, caninelike; lateral line complete; pelvic insertion behind base of pectoral under base of fourth dorsal spine; basally pectoral, dorsal, anal, soft rays, covered with scales of somewhat smaller size than on body; second simple lower pectoral ray longest; usually, fourth dorsal spine longest; rear margin of caudal fin very slightly rounded; upper and lower rays of caudal fin of about same length; posterior margin of preopercle finely denticulate.

Color in alcohol.-Background coloration brown with traces of five vertical dark-brown bars, separated by paler interspaces; upper edge of caudal peduncle with last bar intensified to form a dark blotch, then pale interspace with a dark spot at base of upper caudal rays; body with numerous tiny white or silvery specks; these occurring on basal half of pectoral fin, rather faint on caudal, absent on belly, but present on ventral side of head; pelvics dusky.

Remarks.-This new species may be distinguished from all others referred to the genus Cirrhitus by the presence of the tiny white specks; also it has low orbital ridges but no ridge extending posteriorly from dorsal edge of eye, as in $C$. nigropunctatus.

CIRRHITUS NIGROPUNCTATUS, new species

Plate 13, B

Holotype--U.S.N.M. No. 13218, Mauritius Island, 1872-3, Col. N. Pike.

Paratypes.--U.S.N.M. No. 149584, Mauritius Island, 1872-3, Col. N. Pike. 
Description.-The following counts are recorded first for the holotype, then for the two paratypes: Dorsal rays $\mathrm{X}, 11 ; \mathrm{X}, 11 ; \mathrm{X}, 11$; anal III, 6 ; III, 6 ; III, 6 ; pectoral i, 6 , vii in both fins on all specimens; pelvics always I, 5 ; branched caudal fin rays always $7+6$; vertical scale rows from upper edge of gill opening to base of caudal fin $42 ; 42 ; 41$; scales from dorsal origin to lateral line $4 \frac{1}{2} ; 4 \frac{1}{2} ; 41 \frac{1}{2}$; and from anal origin to lateral line $9 ; 9 ; 9$; gill rakers first gill arch $6+1+10 ; 6+1+10 ; 6+1+11$; scale rows in front of dorsal origin 7 .

Certain measurements were made on the types, and these data, expressed in thousandths of the standard length, are recorded in table 1.

Greatest depth 3.2 to 3.3 ; head 2.7 to 2.8 ; length of longest branched pectoral ray 4.8 to 4.9 ; longest lower simple pectoral ray 3.4 to 3.7 ; all in the standard length. Snout 3.0 to 3.1 ; eye to 4.6 to 5.2 ; tip of snout to rear of maxillary 2.5 ; greatest depth 1.1 to 1.2 ; least depth of caudal peduncle 3.0 to 3.1 ; postorbital length of head 1.8 to 1.9 ; interorbital space (bony) 6.9 to 7.3 ; least suborbital width 6.5 to 7.4 ; all in the length of the head. Least depth of caudal peduncle in its length 2.0. Bony interorbital space 1.4 to 1.8 .

Greatest depth opposite front of base of spiny dorsal; head blunt, profile of snout steep; interorbital space deeply concave, gill membranes broadly joined across isthmus, free, with numerous fine, embedded scales; maxillary concealed under preorbital anteriorly; lips thick, broad; lower jaw a little shorter than upper; mouth slightly oblique; cheeks with fine embedded scales in about 20 rows; nostrils separated by a dermal isthmus, rear margin of anterior nostril with a tuft of cirri; posterior tips of dorsal spines each with a tuft of dermal cirri; no accessory pelvic scale; scales cycloid, absent on snout and dorsal part of head; vomer with a triangular patch of villiform teeth; palatines with a single row of minute teeth; jaws with a band of villiform teeth, broad anteriorly along outer margin of which are short somewhat caninelike conical teeth; lateral line complete; pelvic insertion behind base of pectoral, under base of fourth dorsal spine; basally, soft dorsal, anal, and pectoral rays are covered with minute scales; second simple lower pectoral ray longest; rear margin of caudal fin truncate, ventral most branched caudal fin ray longest; posterior margin of preopercle finely denticulate.

Color in alcohol.-Background coloration very light brown, with five darker-brown broad bars dorsally fading ventrally, the first two separated by a pale interspace extending ventrally from between bases of third and fifth dorsal spines; dark bars 2 and 3 separated by a pale blotch below base of eighth to ninth dorsal spine; dark bars 3 and 4 separated by a pale blotch opposite bases of third to sixth soft dorsal rays; dark bar 5 on caudal peduncle has a white interspace 
fore and aft; pectoral, anal, and caudal fins barred; head and body peppered with numerous scattered, tiny, dark-brown or blackish specks.

Remarks.-C.nigropunctatus is distinct from pinulatus because of its color pattern of minute dark-brown specks on a light-brown and barred background coloration; also the orbital ridges are more prominent. This new species may be separated from all others in the genus by means of the accompanying key.

\title{
CIRRHITUS SPILOTOCEPS, new species
}

\author{
Plate 13, C
}

Cirrhitus maculosus (Lacepède) Rüppect, Atlas zu der Reise im nördlichen Afrika, Fische des rothen Meers, p. 13, pl. 4, fig. 1, 1828 (Red Sea) (substitute spelling for Cirrhitus maculatus Lacepède, but not same species as Cirrhitus maculatus Lacepède).

Holotype.-U.S.N.M. No. 47598, Red Sea, L. M. McCormick. Paratype.-U.S.N.M. No. 149583, Red Sea, L. M. McCormick.

Description.-The following counts are recorded first for the holotype, then for the paratype: Dorsal rays X, 11; X, 10; anal III, 6 ; III, 6 ; pectoral i, 6 , vii-i, 6 , vii ; i, 6 , vii-1, 6, vii ; pelvics I, 5; I, 5; branched caudal fin $7+6 ; 7+6$; vertical scale rows crossing lateral line $42 ; 42$; scales from dorsal origin to lateral line $5 ; 5$; and from anal origin to lateral line $9 ; 9$; gill rakers $6+1+13 ; 6+1+12$; scale rows in front of dorsal origin $7 ; 7$.

Certain measurements were made on the types, and these data, expressed in thousandths of the standard length, are recorded in table 1.

Greatest depth 2.9; head 2.7; length of longest branched pectoral ray 5.2 to 5.3 ; longest lower simple pectoral ray 4.3 to 4.5 ; all in the standard length. Snout 2.8 to 3.0 ; eye 5.2 to 5.4 ; tip of snout to rear of maxillary 2.3 ; greatest depth 1.1 ; least depth of caudal peduncle 3.0 to 3.2 ; postorbital length of head 1.9 ; bony interorbital space 6.9 to 7.0 ; least suborbital width (bony) 5.8 ; all in the length of the head. Least depth of caudal peduncle in its length 1.7 to 1.8. Bony interorbital space 1.3 to 1.4 in eye.

Greatest depth opposite front of spiny dorsal base; head blunt, profile of snout steep; interorbital space concave, orbital ridge low; gill membranes broadly joined across isthmus, free, with numerous fine embedded scales; maxillary concealed by preorbital anteriorly; lips thick, broad; lower jaw a little shorter than upper; mouth a little oblique; cheeks with very fine, embedded scales; nostrils separated by a dermal isthmus, rear margin of anterior one with a tuft of dermal cirri; posterior tips of dorsal spines each with a tuft of dermal cirri; no pelvic accessory scale; scales cycloid; vomer with a triangular patch of villiform teeth; palatines with a few tiny teeth anteriorly in a small 
patch or absent; jaws with a villiform band of teeth, broadest anteriorly along outer margin of which are a few short caninelike conical teeth; lateral line complete; pelvic insertion behind base of pectorals under base of third or fourth dorsal spine; basally the rays of dorsal, anal, and pectoral fins have small scales; second simple lower pectoral ray longest; rear margin of caudal fin slightly rounded; posterior margin of preopercle finely denticulate.

Color in alcohol.-Body marbled with dark-brown and paler blotches more or less forming five vertical bars, somewhat interconnected; head with numerous dark-brown spots, especially on snout, cheeks, and lips; dorsal, anal, pectoral, and caudal fins barred with dark-brown spots; pelvic dusky; anal with a few spots; belly plain light brown; no dark spots or white specks on body.

Remarks.-This species is closest to $C$. pinnulatus but differs in having dark-brown spots on the head, instead of brown streaks, and in lacking blackish or brownish spots on the body. It may be separated from all species referred to the genus Cirrhitus by means of the key.

TABLE 1.-Measurements imade on four species of Cirrhitus, expressed in thousandths of the standard length.

\begin{tabular}{|c|c|c|c|c|c|c|c|c|}
\hline \multirow{2}{*}{ Character } & \multicolumn{3}{|c|}{$\begin{array}{c}\text { nigropunctatus, new } \\
\text { species }\end{array}$} & \multicolumn{2}{|c|}{$\begin{array}{l}\text { albopunctatus, } \\
\text { new species }\end{array}$} & \multicolumn{2}{|c|}{$\begin{array}{l}\text { 3pilotoceps, new } \\
\text { species }\end{array}$} & \multirow{2}{*}{$\begin{array}{l}\begin{array}{l}\text { alterna- } \\
\text { tus Gill }\end{array} \\
\begin{array}{c}\text { Holo- } \\
\text { type }\end{array}\end{array}$} \\
\hline & $\begin{array}{l}\text { Holo- } \\
\text { type }\end{array}$ & Para & pes & $\begin{array}{l}\text { Holo- } \\
\text { type }\end{array}$ & $\begin{array}{l}\text { Para- } \\
\text { type }\end{array}$ & $\begin{array}{l}\text { Holo- } \\
\text { type }\end{array}$ & $\begin{array}{l}\text { Para- } \\
\text { type }\end{array}$ & \\
\hline Standard length in millimeters..... & 138 & 148 & 121 & 99.5 & 80 & 181 & 156 & 108 \\
\hline Length of head & 362 & 378 & 366 & 360 & 375 & 370 & 378 & 393 \\
\hline Snout._. & 116 & 124 & 113 & 112 & 111 & 124 & 128 & 133 \\
\hline Eye. & 74 & 71 & 78 & 67 & 80 & 69 & 74 & 81 \\
\hline Postorbital length of head.............. & 179 & 199 & 186 & 199 & 205 & 197 & 194 & 205 \\
\hline Greatest depth & 315 & 324 & 312 & 330 & 338 & 343 & 333 & 370 \\
\hline Least depth of caudal peduncle.... & 113 & 118 & 112 & 139 & 139 & 120 & 125 & 130 \\
\hline Length of caudal peduncle & 243 & 234 & 236 & 215 & 219 & 224 & 218 & 204 \\
\hline Snout tip to dorsal origin........... & 344 & 365 & 355 & 372 & 376 & 368 & 363 & 389 \\
\hline Snout tip to anal origin & 652 & 655 & 660 & 684 & 698 & 680 & 705 & 660 \\
\hline Snout tip to rear of maxillary & 148 & 162 & 145 & 156 & 171 & 160 & 165 & 168 \\
\hline Bony interorbital space & 51 & 55 & 44 & 50 & 53 & 55 & 54 & 49 \\
\hline Longest simple pectoral ray ............ & 291 & 288 & 293 & 231 & 281 & 227 & 234 & 240 \\
\hline Longest dorsal spine & 134 & 132 & 144 & 116 & 122 & 149 & 147 & 149 \\
\hline Longest anal spine & 156 & 155 & 152 & 148 & 135 & 144 & 140 & 156 \\
\hline Longest caudal fin ray & 235 & 237 & 240 & 210 & 221 & 196 & 224 & 250 \\
\hline Length of pelvic fins & 185 & 181 & 193 & 211 & 218 & 210 & 202 & 225 \\
\hline Least suborbital width & 54 & 53 & 42 & 50 & 50 & 71 & 65 & 65 \\
\hline
\end{tabular}




\section{$2 \mathrm{BHL}$ Biodiversity Heritage Library}

Schultz, Leonard P. 1950. "Three new species of fishes of the genus Cirrhitus (family Cirrhitidae) from the Indo-Pacific." Proceedings of the United States National Museum 100(3270), 547-552.

https://doi.org/10.5479/si.00963801.100-3270.547.

View This Item Online: https://www.biodiversitylibrary.org/item/53452

DOI: https://doi.org/10.5479/si.00963801.100-3270.547

Permalink: https://www.biodiversitylibrary.org/partpdf/52113

\section{Holding Institution}

Smithsonian Libraries

\section{Sponsored by}

Smithsonian

\section{Copyright \& Reuse}

Copyright Status: Public domain. The BHL considers that this work is no longer under copyright protection.

This document was created from content at the Biodiversity Heritage Library, the world's largest open access digital library for biodiversity literature and archives. Visit BHL at https://www.biodiversitylibrary.org. 